Article

\title{
Acceptance of Main Power Generation Sources among Japan's Undergraduate Students: The Roles of Knowledge, Experience, Trust, and Perceived Risk and Benefit
}

\author{
Lingling Wang ${ }^{1, *}$, Tsunemi Watanabe ${ }^{2}$ and Kyohei Wakui ${ }^{3}$ \\ 1 Department of Civil Engineering, School of Regional Design, Utsunomiya University, \\ Utsunomiya 321-8585, Japan \\ 2 School of Economics \& Management, Kochi University of Technology, Kochi 780-8515, Japan; \\ watanabe.tsunemi@kochi-tech.ac.jp \\ 3 Urban Infrastructure Development Department, Ota City Hall, Tokyo 144-8621, Japan; \\ w.wack.0912@gmail.com \\ * Correspondence: lingling@cc.utsunomiya-u.ac.jp
}

Citation: Wang, L.; Watanabe, T.; Wakui, K. Acceptance of Main Power Generation Sources among Japan's Undergraduate Students: The Roles of Knowledge, Experience, Trust, and Perceived Risk and

Benefit. Sustainability 2021, 13, 12416. https://doi.org/10.3390/su132212416

Academic Editor: Lin Li

Received: 27 August 2021

Accepted: 8 November 2021

Published: 10 November 2021

Publisher's Note: MDPI stays neutral with regard to jurisdictional claims in published maps and institutional affiliations.

Copyright: (c) 2021 by the authors. Licensee MDPI, Basel, Switzerland. This article is an open access article distributed under the terms and conditions of the Creative Commons Attribution (CC BY) license (https:/ / creativecommons.org/licenses/by/ $4.0 /)$.

\begin{abstract}
In Japan, graduates who become independent professionals in society have the right to choose energy providers given the liberalization of the electricity market in the country. This issue renders student perceptions regarding various types of energy generation a critical factor for decision making. Accordingly, we explored the risk and benefit perceptions of undergraduates regarding Japan's main energy resources, namely, liquid natural gas (LNG), coal, hydropower, solar and nuclear resources, and petroleum. We also assessed energy acceptance among the target population and its influencing factors, such as student age and gender, school department, hometown, knowledge and experience of main power sources in Japan, and trust in government and power plant operation. These objectives were accomplished through field surveys and empirical characterizations of energy acceptance determinants. Compared with risk perception, benefit perception regarding all kinds of power generation was significantly predicted by knowledge. Experience explained only the perception of benefit from coal power generation, and benefit perception more strongly predicted energy acceptance than did risk perception. The findings suggested the necessity of university energy education programs for increased student knowledge of energy sources. Energy companies should increase energy benefits from economic, environmental, and energy security and safety perspectives to enhance energy acceptance among students. On the basis of the results, we classified energy sources in Japan into obscure (LNG and petroleum), well-known (coal and nuclear), and exploratory (hydropower and solar) resources-a first in the energy field and contributory to energy education design.
\end{abstract}

Keywords: energy awareness; personal corporate social responsibility; risk and benefit perception; Japan

\section{Introduction}

The energy situation in Japan is extremely serious, and the lack of local conventional energy sources resulted in an energy self-sufficiency rate in the country of only $9.6 \%$ in 2017 [1]. This problem has rendered Japan almost totally dependent on imported coal, liquid natural gas (LNG), and petroleum for power generation. After the nuclear explosion in 2011, the ensuing shutdown of the concerned nuclear power plant increased the country's dependence on fossil fuels to $87.4 \%$ in 2017 [1]. Aside from these issues, supply stability and unstable pricing cause considerable concern among the Japanese government, researchers, and residents. The good news is that, since the Great East Japan Earthquake, power generation from nuclear sources has been reduced to almost zero. In 2017, the government approved a policy revision allowing the establishment of purchase prices through public tender for the new feed-in tariff (FIT), whose introduction was aimed 
at alleviating the burdens borne by electricity users [2]. With the growth of advocacy for the development of renewable energy, aggressive renewable energy targets have been proposed. For example, the Fourth Strategic Energy Plan sets a goal of 22\% to $24 \%$ as the renewable energy share out of the total power generation by 2030 [3]. A target of $100 \%$ electricity production from renewable energy by 2050 has been proposed [4]. The year 2017 saw the percentage of power generation through renewable energy in Japan increase to $16.0 \%$, ranking the country sixth in the world in terms of capacity for renewable energy generation and third with respect to solar power generation [5]. Despite these gains, however, comparisons with circumstances in foreign countries indicated that a rise in FIT levy accompanies the expansion of renewable energy-based electricity generation, thereby leading to user opposition to the high costs of supporting such production [6]. The Japanese government has also begun eliciting considerable attention because of the possibility that promoting renewable energy will impose heavy burdens on households in the near future $[7,8]$. The increase in low-income households in Japan due to aging and a continuing sluggish economy has rendered vulnerable households more sensitive to rising living costs, including those related to energy. Thus, renewable energy development and energy cost regulation are critical topics in energy policymaking.

The Great East Japan Earthquake and the subsequent accident involving the Fukushima Daiichi Nuclear Power Plant in March 2011 inspired new attempts to increase citizen participation in forming energy policy in Japan. Among these attempts is the Japanese government's series of participatory studies on innovative post-Fukushima energy and environmental strategies, including random sampling-based citizen deliberation or deliberative polling [9]. Indeed, public opinion notably affected Japan's nuclear energy policy after the Fukushima disaster $[10,11]$. In particular, the enactment of full electricity market liberalization in April 2016, in response to increased competition and reduced prices, enabled electricity customers to choose energy providers $[12,13]$. The overall rate at which power consumers in Japan switched from general electricity utilities (GEUs) to power producers and suppliers (PPSs) has steadily increased from almost zero before the electricity market liberation to $12.7 \%$ by the end of 2017 [14]. A consumer survey also found that $60 \%$ of existing consumers want to shift to PPSs for their electricity supply and that $98.5 \%$ of switching users are extremely happy with such a decision and their overall experience with the switch [15]. Correspondingly, under the competitive electricity supply market in Japan, consumers' attitudes toward different methods of energy generation have become critical.

Many studies have analyzed consumers' willingness to pay (WTP) for renewable energy using contingent valuation (CV) methods, which are often employed in estimations of the economic value of non-market goods and services. For example, Hite et al. studies willingness to pay for biopower [16]; a study by Mozumder et al. also applies CV to investigate consumers' preference for renewable energy [17]; to build a sound energy system to protect environment, Nomura uses the willingness-to-pay method to investigate Japanese households [18]; and Whitehead and Cherry also apply willingness-to-pay for studying green energy program [19]. Previous research has also investigated the attitudes and decision making of consumers with respect to multiple energy resources $[20,21]$. However, a review of the open literature revealed a scarcity of energy education studies in Japan despite the issue that undergraduate consumers have insufficient knowledge and experience for wise decision making on energy consumption. Most previous studies are related to energy technologies, such as solar energy system [22]; application sources, such as energy consumption and greenhouse gas emissions system [23,24]; and energy policy economics on publics, for example, proposing energy policy in Iran [25], a comparison study between Thailand and Vietnam on public' risk and benefit perception, as well as acceptance of nuclear power [26] and the public's perception on nuclear power in China [27]. As university students are the populations that are the earliest to enter society and make energy consumption decisions under the electricity market liberalization policy, a vital task is to investigate their perceptions toward energy generation methods. Moreover, increasing undergraduates' energy knowledge for their wise decision in the near future is also their 
university's social responsibility, which can product positive impact on society through high education, research, the transfer of knowledge and technology, as well as education for sustainability [28].

In view of the above-mentioned deficiency, the primary motivation of the current research was the need to generate and analyze reliable data that can underpin evidencebased energy education programs for undergraduate students. The study's contributions toward achieving this aim are as follows: (1) it explored the risks and benefits perceived by undergraduates regarding various energy sources from environmental, economic efficiency, and energy security and safety (3Es + S) perspectives; (2) it probed into the determinants of risk and benefit perceptions among the target population; and (3) it investigated how energy acceptance among undergraduates is affected by risk and benefit perceptions. The methodology used to examine such micro-level energy perceptions involved conducting a representative survey and an in-depth statistical analysis of the results for the formulation of evidence-based energy education programs. To the best of our knowledge, this research is the first to measure the manner by which undergraduates perceive the importance and prioritization of different energy sources on the basis of environmental, economic efficiency, and energy security and safety standpoints. Risk and energy perceptions were also used as grounding in an examination of energy acceptance among the target population. The results are the first empirical evidence of energy-related risk and benefit perceptions among undergraduates and their determinants. They can also have significant implications for the selection of energy providers and, accordingly, serve as a basis for energy education and energy policymaking. Finally, the findings are expected to stimulate a discussion of how factors, such as knowledge, experience, trust, and sociodemographic segmentation, can influence undergraduates' perceptions of risks and benefits from different energy sources. All these factors lead to energy acceptance.

\section{Background and Research Hypotheses}

\subsection{Energy Policy Direction}

The Japanese cabinet-adopted document sets the basic direction to be followed in national energy policymaking for the next two decades in line with the fundamental principles shown in Table 1. Generally, energy policymaking entails two stages (Table 1).

Table 1. Energy policy direction.

\begin{tabular}{|c|c|c|}
\hline & Pre-Fukushima Nuclear Disaster & Post-Fukushima Nuclear Disaster \\
\hline Energy policy direction & $\begin{array}{l}\text { 3Es: Energy security, environmental } \\
\text { protection, and efficient supply [29] }\end{array}$ & $\begin{array}{l}\text { 3Es + S: Energy security (self-sufficiency } \\
\text { rate), economic efficiency (electricity cost), } \\
\text { environment [greenhouse gas (GHG) } \\
\text { emissions], and safety as a pillar of national } \\
\text { energy policy [3] }\end{array}$ \\
\hline Target & $\begin{array}{l}\text { Reduce domestic energy-related } \mathrm{CO}_{2} \\
\text { emissions by around 30\% lower than } 1990 \\
\text { levels by } 2030\end{array}$ & \multirow[b]{2}{*}{$\begin{array}{l}\text { Nuclear power generation should be reduced } \\
\text { as much as possible, which calls for a swift } \\
\text { restart of existing nuclear power plants } \\
\text { following safety approval from the Nuclear } \\
\text { Regulation Authority (NRA). Under the } \\
\text { considerable premise of safety, the energy } \\
\text { self-sufficiency rate is projected to increases } \\
\text { to } 25 \% \text { in } 2030 \text {, which is } 5 \% \text { higher than the } \\
\text { level achieved before the Great East Japan } \\
\text { Earthquake (the current self-sufficiency rate } \\
\text { is } 9.6 \% \text { ). Electricity cost is expected to } \\
\text { decrease to } 9.5 \text { trillion yen by } 2030 \text {. }\end{array}$} \\
\hline Approach & $\begin{array}{l}\text { Build } 14 \text { new nuclear power plants by } 2030 \text { in } \\
\text { addition to the existing } 54 \text { since } 2010 \\
\text { This nuclear power expansion plan would } \\
\text { have increased the installed generation } \\
\text { capacity from } 49 \text { GWe in } 2010 \text { to } 60 \text { GWe in } \\
2020 \text { and } 68 \text { GWe in } 2030 \text {, as well as the } \\
\text { electricity generation capacity from } 288 \text { TWh } \\
\text { in } 2010 \text { to approximately } 540 \text { TWh, or nearly } \\
\text { half the total centralized power generation } \\
\text { in } 2030 \text { [30]. }\end{array}$ & \\
\hline
\end{tabular}




\subsection{Deregulation and Liberalization in the Electricity and Gas Market}

During the post-Fukushima period, deregulation policies and the liberalization of the electricity and gas market compelled energy firms to focus more strongly on innovative and newer technologies, rather than on institutional barriers and highly regulated markets to reduce costs and ensure safer environmentally sourced power. The institutional reforms were intended to position Japan in a competitive electricity market, with prices set on the basis of supply and demand [31]. As of 2016, the Japanese power market was valued at about JPY 18.2 trillion, out of which the regulated energy sector accounted for JPY 8.1 trillion before competition was opened in 2016 [32]. These developments served as a powerful incentive for existing firms to realign themselves with the new institutional landscape and for new companies to penetrate the newly liberalized market. Regional monopoly companies began relinquishing their dominance in the market and joining the competition in one another's markets. International markets also became targets for greater competition. For example, instead of heavily relying on trading companies for import fuels, Japan Energy Era, Chugoku Electric, and Chubu Electric started investing in overseas energy projects [33]. Along with the advancement of liberalization, households switched from monopolized electric companies to newly emerging electric power companies, with the number of switching consumers reaching 10.6\% in June 2017 (Figure 1) [34]. This increase paved the way for an expansion of the market where new electric companies operate- $\mathrm{A}$ development that reduced the electricity pressure used in households and enabled the use of extra high and high pressure by factories. The market share of new electric companies accordingly reached 11.3\% in June 2017 (Figure 2) [34]. The deregulation and liberalization of the electricity market accorded customers the right to choose electricity companies from which to acquire services. Amid this backdrop, the perceptions of customers have become increasingly important in the selection of power providers.

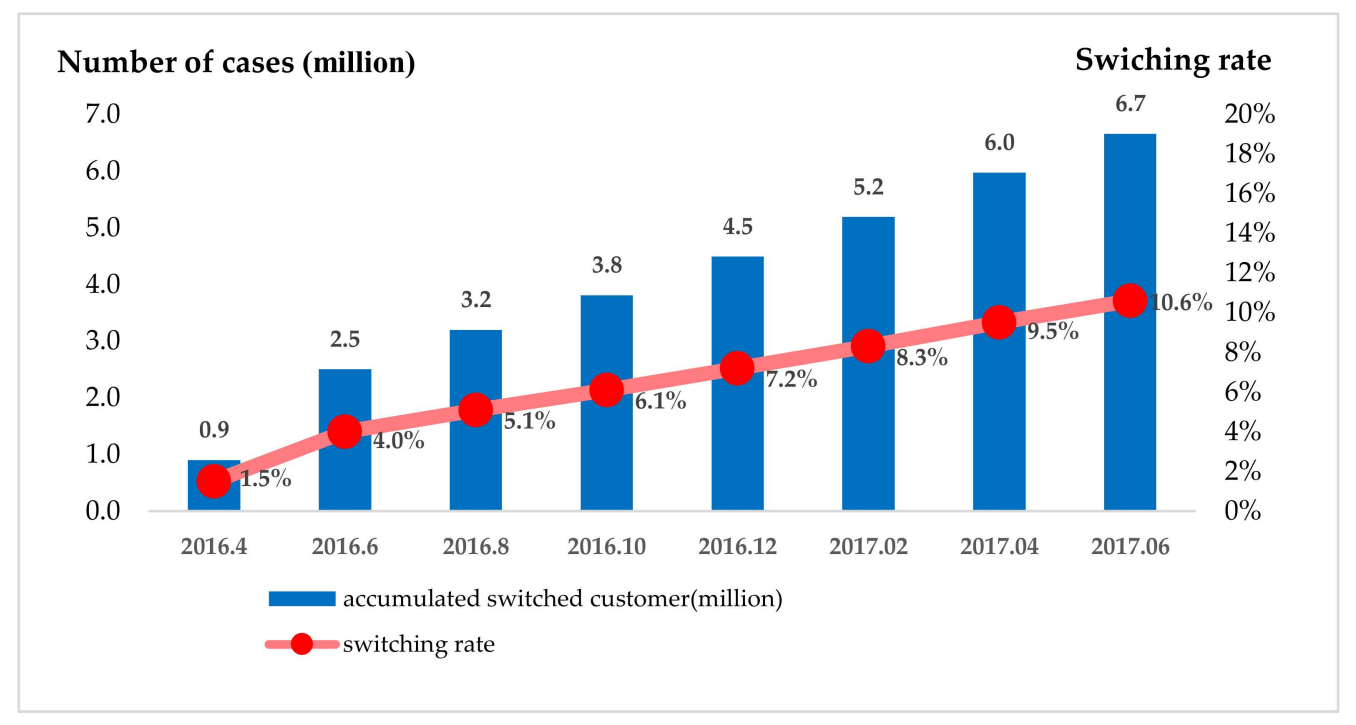

Figure 1. Transition of switching cases after liberalization in the electricity market. 


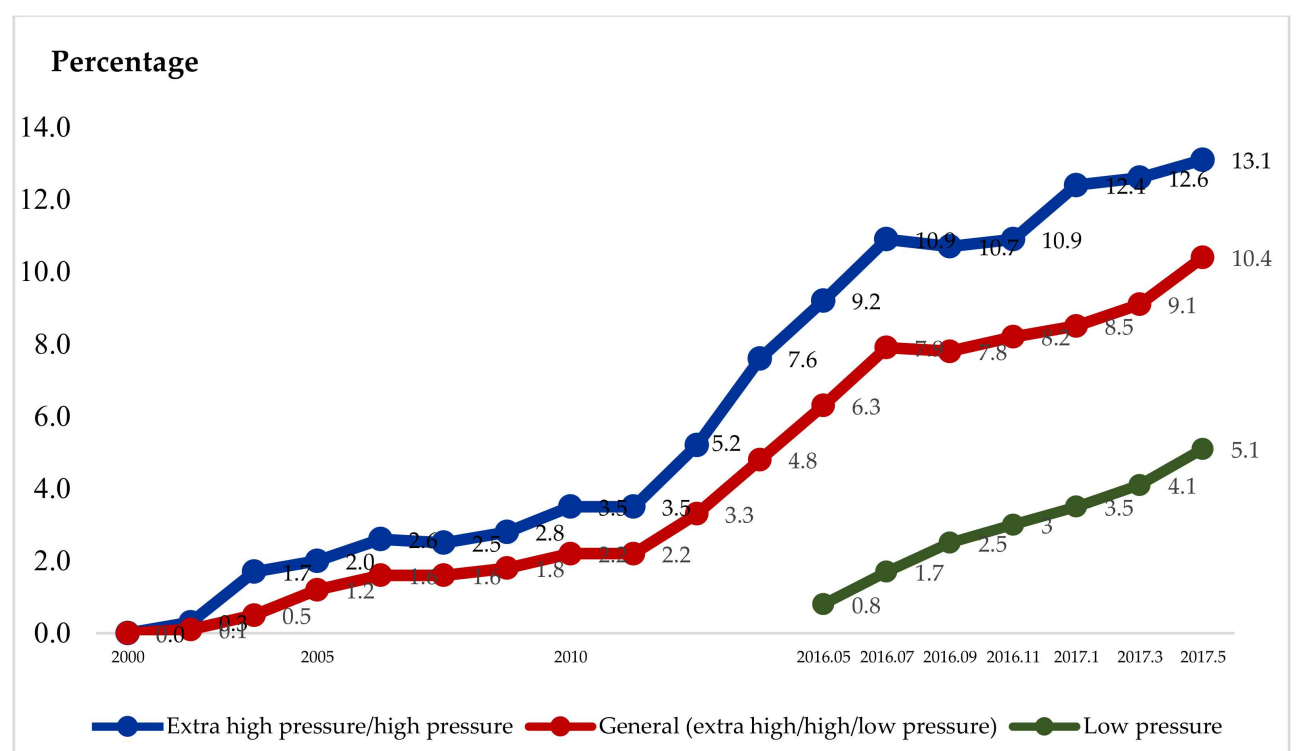

Figure 2. Market share transition after liberalization in the electricity market. (Notes: Extra high pressure is used by large-scale factories, whereas high pressure is used in middle- and small-scale factories. Low pressure is used in households).

\subsection{Factors Affecting Energy Decisions}

\subsubsection{Knowledge, Trust, Experience, Perceived Risks and Benefits}

The public's lack of understanding of many issues negatively affects the ability of the government to represent the will of the people $[35,36]$. Previous studies indicated that an individual's comprehension of a particular technology can influence his/her perception of risks and benefits as regards that technology [37]. People's understanding of different energy sources varies remarkably, although individuals have no professional or clear information about these resources [38]. Considerable knowledge about energy resources that cause environmental pollution can drive an individual to perceive a high risk stemming from energy technologies in general [39]. Zografakis et al. found that respondents who are knowledgeable about renewable energy and its benefits on climate change and energy security are more willing to pay for renewable energy generation [40]. Similarly, other researchers indicated that knowledge-related concepts, such as probability, magnitude of harm, uncertainty, and catastrophic potential, strongly affect risk perception [41,42]. Knowledge of these concepts is commonly found to be a predictor of risk [43,44]. Appropriately evaluating risk necessitates understanding a given issue. For example, an individual's values or institutional factors are unlikely to influence views about the risk of being burned by touching a hot stove, but one's knowledge and experience should [45].

Trust, likewise, plays a vital role in an individual's perceptions regarding energy decisions. Under insufficient experience of a particular energy source, trust can alter an individual's perspectives $[46,47]$. To assess risks and benefits, people may rely on social trust [48] or affective information [49]. Previous studies uncovered that the trust formed in a society or the trust affected by other individuals in a society significantly influences individual perceptions of benefits and risks. In addition, perceived trust indirectly affects users' intention to accept particular technologies via perceptions of benefits and risks. Lastly, previously published results indicated that trust leads to higher perceptions of risks and benefits [50-52].

Past research denoted the importance of experience in the formation of perceptions. As reported by [53], for instance, personal experience is correlated significantly and positively with the public's willingness to pay for renewable energy. Research in the field of natural hazards has consistently found that people who have lived through an event, such as flooding and volcanic eruption, hold higher levels of risk perceptions, particularly if the 
event was severe or resulted in adverse outcomes [54-56]. People who have suffered severe consequences expect the likelihood of future events to be higher and their effects to be more serious [57]. By contrast, mild consequences from an event engender low risk perception [58]. As previously stated, a definitive study on the relationship between experience and benefit perception has not been carried out in the context of energy adoption. On the basis of the energy production paths identified and proposed in previous studies, we sought answers to the following research questions:

RQ1: How does knowledge predict students' perceptions of risks and benefits from different modes of energy generation?

RO2: How is students' perceived trust in various organizations related to energy, and how does trust predict their risk and benefit perceptions?

RQ3: How do previous experiences influence students' risk and benefit perceptions?

\subsubsection{Perceived Risks and Benefits and Acceptance of Energy Sources}

Each energy source presents advantages and disadvantages that add to the complexity of decision making. Renewable energy can reduce GHG emissions and offer additional benefits, such as a decreased need for imported energy sources. Nevertheless, the pursuit of renewable energy entails substantial investment and translates to high electricity costs for consumers, intermittent supply, and associated negative local externalities, such as noise, altered landscapes, and potential harm to birds. Making a wise choice requires consumers to consider both the risks and benefits of each power resource [59].

Previous studies indicated the essentiality of examining the type and degree of technology acceptance among populations [60]. The acceptance of a new technology is strongly driven by perceived benefits and risks $[47,61,62]$. In general, the greater the perception of a certain technology as risky, the less likely people are to accept it [63]. Research also indicated that perceived benefits are more important than perceived risks in explaining technology acceptance [62,64]. The public's acceptance of controversial technologies, such as nuclear energy, has garnered scholarly attention. High levels of perceived benefits increase the likelihood of public acceptance of nuclear energy [65] or reduce opposition against this type of power generation [66]. Perceived economic benefits are a more important driver of nuclear power acceptance than perceived risks, but mixed results have been derived as to the effectiveness of perceived environmental benefits in predicting the public's acceptance of nuclear energy [67].

These insights are valuable, but no study has been directed to how perceived benefits and risks predict the acceptance of other energy sources, such as LNG, coal, solar power, and hydropower. The present study therefore endeavored to understand and compare students' perceptions of risks and benefits as well as their acceptance of power generation methods in Japan. This brings us to the fourth question illuminated in this work:

RQ4: What are the differences in students' perceptions of risks and benefits and acceptance levels with regard to various power generation methods/sources in Japan? How do perceived risks and benefits predict energy acceptance among this population?

Among many energy surveys, those anchored in citizens' opinions and a hypothesisbased approach are the most complete and accurate methods [68]. Studies that involved citizen-opinion surveys have produced complex and compositive results on psychological, sociodemographic, and cognitive factors [69]. Therefore, a conceptual model that incorporates these factors can be helpful and constructive in understanding and improving users' acceptance of availing electricity services and behavioral intention to do so. On these bases, we put forward the following suppositions (Figure 3): 


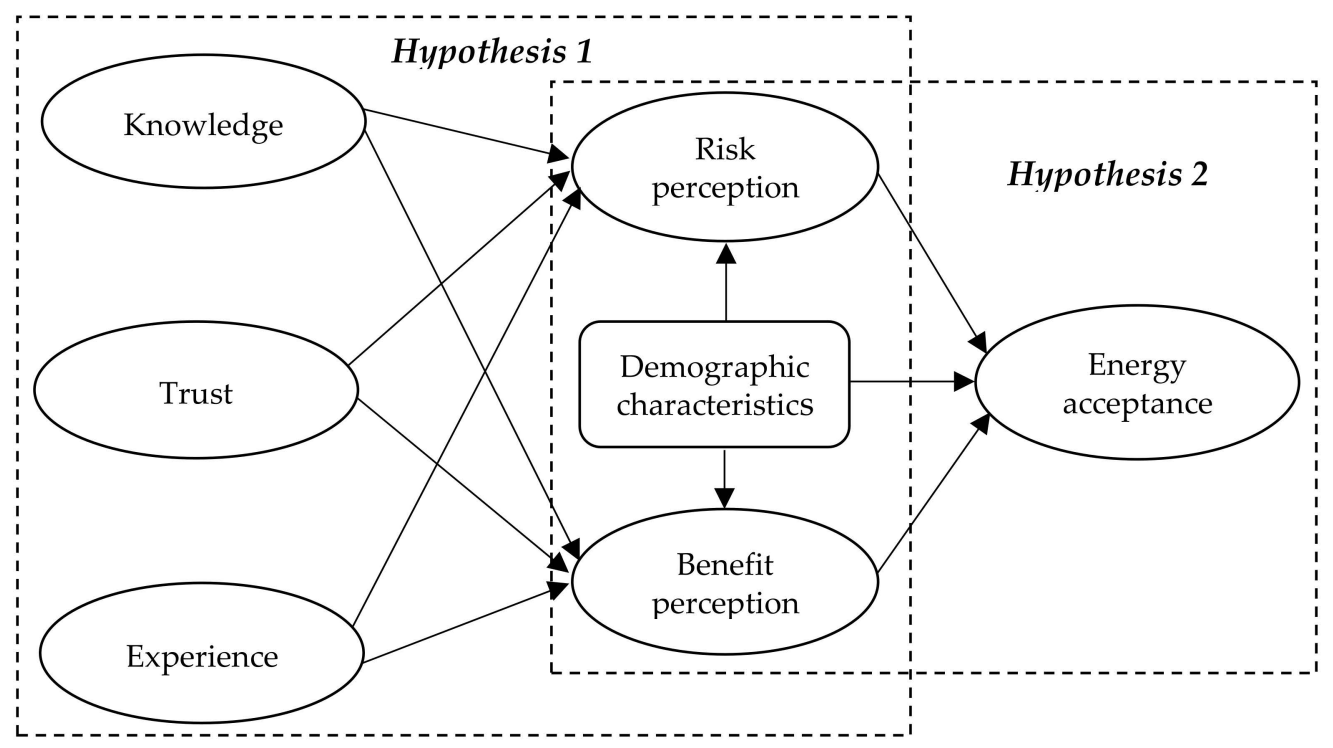

Figure 3. Hypothesis framework for testing.

Hypothesis H1. Students' risk and benefit perceptions in relation to energy sources are determined by sociodemographic characteristics, knowledge, trust, and experience.

Hypothesis H2. Students' energy acceptance is determined by their perceptions of risks and benefits from power sources.

\section{Methods and Data}

\subsection{Data}

This study was carried out from September to December 2019 using a questionnaire and qualitative methods. To guide the development of a formal questionnaire and Liker scales, we conducted a qualitative survey using semi-structured interviews with key informants (age, gender, affiliation, year level, and hometown). We used a pilot study to uncover possible misinterpretations of the questions and ambiguous responses. In addition, we gathered qualitative data through focus group interviews and participant observations to help us better understand students' perception. The empirical data collected from the survey were analyzed to determine risk and benefit perceptions regarding the main energy sources in Japan (LNG, coal, hydropower, solar and nuclear power, petroleum), the influencing factors of such perceptions, and energy acceptance among Japanese undergraduates. In addition to perceived risks and benefits as well as energy acceptance, sociodemographic information and the influencing factors of the aforementioned perceptions were indicated in the survey data. Sociodemographic information included age, gender, hometown, year level, and departmental affiliation. The information on determinants included that related to knowledge, trust, and experience. The core survey responses came from northeastern Japan, given that, after the nuclear power explosion in Fukushima in 2011, people in this region may have developed a stronger awareness of energy. Figure 4 shows the percentages of respondents hailing from different parts of Japan. A total of 151 questionnaires were eliminated because of missing data, leaving us with a final sample of 216. We hypothesized that the variables used in this study are important determinants of students' perceptions of risks and benefits. Table 2 summarizes the definition of each variable used in our analysis. 


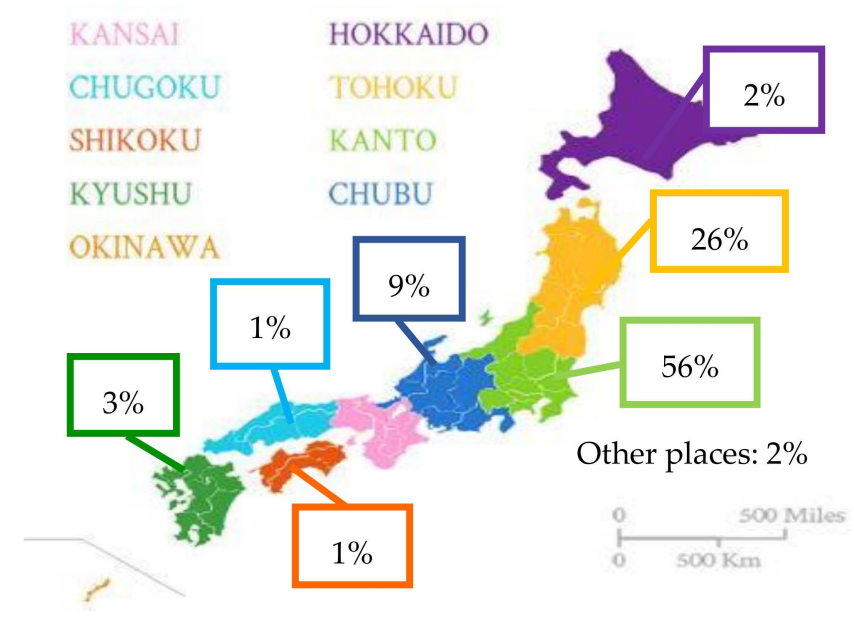

Figure 4. Distribution of respondents.

Table 2. Description of the variables.

\begin{tabular}{|c|c|c|}
\hline & Variable & Description \\
\hline \multirow{4}{*}{ Perceived risk and benefit } & Economic perspective & Related to power generation cost \\
\hline & Environmental perspective & Related to air pollution and global warming \\
\hline & Stable supply perspective & Related to stable power supply for residents \\
\hline & Safety perspective & Related to the safe management of power plant operation \\
\hline Acceptance & Support level & Acceptance of power sources \\
\hline \multirow{3}{*}{ Knowledge } & \multirow{3}{*}{ Characteristics of power generation } & Advantages and disadvantages \\
\hline & & Power generation ratio \\
\hline & & Power generation process \\
\hline \multirow{2}{*}{ Experiences } & \multirow{2}{*}{ Personal experience and experience from people around } & $\begin{array}{l}\text { Experience of internship in power plants or visits to } \\
\text { power plants }\end{array}$ \\
\hline & & Friends or relatives having worked in power plants \\
\hline \multirow{3}{*}{ Trust } & \multirow{3}{*}{$\begin{array}{l}\text { Trust in the management of power plants, the } \\
\text { government, and specialists }\end{array}$} & Information provided by power plants \\
\hline & & Information provided by the government \\
\hline & & Information provided by experts \\
\hline \multirow{6}{*}{ Sociodemographic } & Age & \multirow{6}{*}{$\begin{array}{l}\text { Numeric } \\
\text { Male; female } \\
\text { Fukushima and neighboring prefectures; } \\
\text { other prefectures } \\
\text { Freshman to senior } \\
\text { Schools affiliated with science and engineering } \\
\text { disciplines and schools affiliated with the social sciences }\end{array}$} \\
\hline & Gender & \\
\hline & Hometown & \\
\hline & Year level & \\
\hline & Affiliation & \\
\hline & & \\
\hline
\end{tabular}

\subsection{Dependent and Independent Variables}

In keeping with Hypothesis 1, two dependent variables were analyzed: the risk and benefit perceptions of students regarding the main energy sources in Japan (Figure 5 [70]) The questionnaire dealt with LNG, coal, hydropower, solar and nuclear power, and petroleum, which are the most extensively used power sources in Japan. With reference to the advantages and disadvantages of these power sources, the respondents were asked to answer questions on risk and benefit perceptions related to economic efficiency, the environment, and energy security and safety. Consistent with Hypothesis 2, energy acceptance served as a dependent variable. Table 3 provides brief descriptions of students' risk and benefit perceptions as well as their acceptance of various power sources. With students' evaluation of completely disagree $(=1)$ and completely agree $(=5)$, the mean value and standard deviation are shown in Table 3. The students exhibited the highest risk perception toward nuclear power generation (3.94) and the highest benefit perception toward solar power generation (3.68). The perception of benefit from nuclear power generation was the second highest. The acceptance of nuclear power was the lowest (2.49), whereas 
that of solar energy was the highest (3.61). Overall, the students' risk perception was higher than their benefit perception. Their acceptance of Japan's main power sources was of a moderate level. Table 4 describes the mean value and the standard deviation of dependent variables in this study. Knowledge of nuclear power was the highest (3.244), while LING was the lowest (2.375). There was not big difference of mean values in experience. Students' trust toward nuclear power was the lowest (2.889).

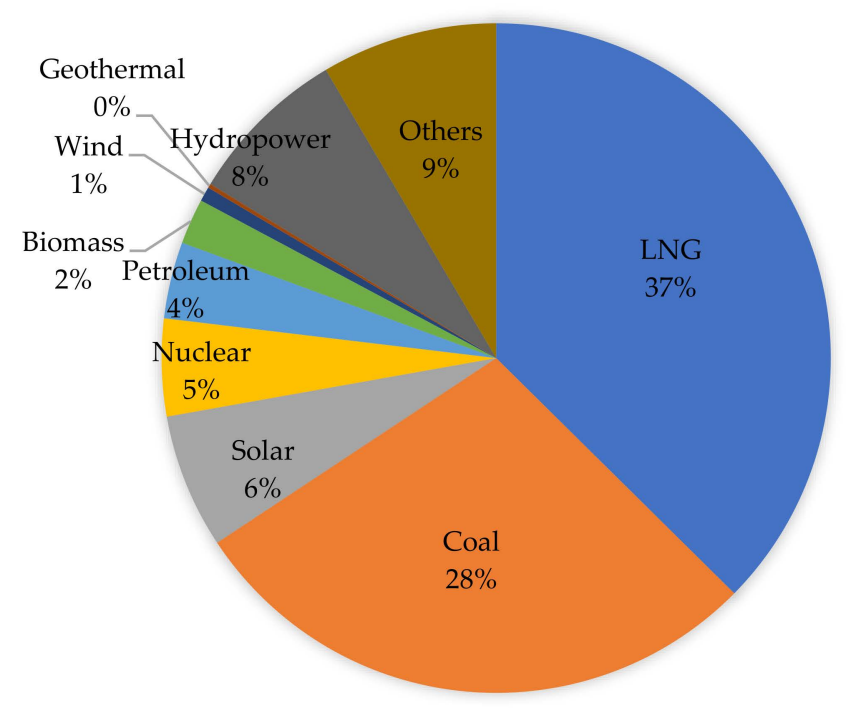

Figure 5. Power supply composition in Japan, 2018.

Table 3. Summary statistics of the independent variables for Hypotheses 1 and 2.

\begin{tabular}{|c|c|c|c|}
\hline Energy Source & Independent Variable & Mean & $\mathrm{SD}^{1}$ \\
\hline \multirow{3}{*}{ LNG } & $\mathrm{RP}_{\mathrm{LNG}}$ & 3.28 & 0.64 \\
\hline & $\mathrm{BP}_{\mathrm{LNG}}$ & 3.19 & 0.66 \\
\hline & Acceptancy ${ }_{L N G}$ & 3.04 & 0.82 \\
\hline \multirow{3}{*}{ Coal } & $\mathrm{RP}_{\text {coal }}$ & 3.84 & 0.70 \\
\hline & $\mathrm{BP}_{\text {coal }}$ & 3.30 & 0.73 \\
\hline & Acceptancy $_{\text {coal }}$ & 2.68 & 0.89 \\
\hline \multirow{3}{*}{ Hydropower } & $\mathrm{RP}_{\text {hydro }}$ & 3.79 & 0.66 \\
\hline & $\mathrm{BP}_{\text {hydro }}$ & 3.40 & 0.67 \\
\hline & Acceptancy hydro & 3.39 & 1.02 \\
\hline \multirow{3}{*}{ Solar } & $\mathrm{RP}_{\text {solar }}$ & 3.37 & 0.68 \\
\hline & $\mathrm{BP}_{\text {solar }}$ & 3.68 & 0.84 \\
\hline & Acceptancy solar & 3.61 & 1.11 \\
\hline \multirow{3}{*}{ Nuclear } & $\mathrm{RP}_{\text {nuclear }}$ & 3.94 & 0.80 \\
\hline & $\mathrm{BP}_{\text {nuclear }}$ & 3.43 & 0.82 \\
\hline & Acceptancy nuclear & 2.49 & 1.22 \\
\hline \multirow{3}{*}{ Petroleum } & $R P_{\text {petroleum }}$ & 3.68 & 0.63 \\
\hline & $\mathrm{BP}_{\text {petoleum }}$ & 3.36 & 0.85 \\
\hline & Acceptancy petoleum $_{\text {par }}$ & 2.69 & 0.93 \\
\hline
\end{tabular}

${ }^{1} \mathrm{SD}=$ standard deviation. 
Table 4. Summary statistics of the dependent variables for Hypotheses 1 and 2.

\begin{tabular}{|c|c|c|c|c|c|}
\hline Energy Source & Dependent Variable & $\begin{array}{c}\text { Mean } \\
/ \mathbf{N}\end{array}$ & $\begin{array}{l}\mathrm{SD}^{1} \\
/(\%)\end{array}$ & $\operatorname{Min}^{2}$ & $\operatorname{Max}^{3}$ \\
\hline \multirow{10}{*}{ Sociodemographics } & Age (years) & 19.55 & 1.152 & 18 & 26 \\
\hline & $1=$ male & 150 & $69.5 \%$ & - & - \\
\hline & $2=$ female & 66 & $30.5 \%$ & - & - \\
\hline & Year level $($ freshman $=1$, sophomore $=2$, junior $=3$, senior $=4)$ & 2.00 & 0.318 & 1 & 4 \\
\hline & Affilia & & & & \\
\hline & $1=$ affiliated to science and engineering & 25 & $11.7 \%$ & - & - \\
\hline & $2=$ affiliated to social science & 191 & $88.3 \%$ & - & - \\
\hline & \multicolumn{5}{|c|}{ Hometown } \\
\hline & $1=$ Fukushima and neighbor prefectures & 112 & $52.0 \%$ & - & - \\
\hline & $2=$ other prefectures & 104 & $48.0 \%$ & - & - \\
\hline \multirow{3}{*}{ LNG } & Knowledge ${ }_{\text {LNG }}$ & 2.375 & 1.062 & 1 & 5 \\
\hline & Experience $_{\text {LNG }}(1=$ yes, $2=$ no $)$ & 1.972 & 0.158 & 1 & 2 \\
\hline & Trust $_{\text {LNG }}$ & 3.103 & 0.760 & 1 & 5 \\
\hline \multirow{3}{*}{ Coal } & Knowledge $_{\text {coal }}$ & 2.843 & 0.963 & 1 & 5 \\
\hline & Experience coa $1(1=$ yes, $2=$ no $)$ & 1.958 & 0.230 & 1 & 2 \\
\hline & Trust coal & 3.139 & 0.751 & 1 & 5 \\
\hline \multirow{3}{*}{ Hydropower } & Knowledge hydro & 3.054 & 1.014 & 1 & 5 \\
\hline & Experience $_{\text {hydro }}(1=$ yes, $2=$ no $)$ & 1.964 & 0.155 & 1 & 2 \\
\hline & Trust hydro & 3.210 & 0.841 & 1 & 5 \\
\hline \multirow{3}{*}{ Solar } & Knowledge solar & 2.935 & 0.943 & 1 & 5 \\
\hline & Experience $_{\text {solar }}(1=$ yes, $2=$ no $)$ & 1.962 & 0.163 & 1 & 2 \\
\hline & Trust solar & 3.217 & 0.855 & 1 & 5 \\
\hline \multirow{3}{*}{ Nuclear } & Knowledge nuclear & 3.244 & 0.998 & 1 & 5 \\
\hline & Experience nuclear $(1=$ yes, $2=$ no $)$ & 1.941 & 0.228 & 1 & 2 \\
\hline & Trust nuclear & 2.889 & 0.909 & 1 & 5 \\
\hline \multirow{3}{*}{ Petroleum } & Knowledge petroleum & 2.701 & 0.984 & 1 & 5 \\
\hline & Experience petroleum $(1=$ yes, $2=$ no $)$ & 1.977 & 0.129 & 1 & 2 \\
\hline & Trust petroleum & 3.119 & 0.788 & 1 & 5 \\
\hline
\end{tabular}

${ }^{1} \mathrm{SD}=$ standard deviation; ${ }^{2} 1=$ completely disagree; ${ }^{3} 5=$ completely agree.

\subsection{Data Analysis}

In the near future, an increasing number of Japanese consumers can choose sources from which to derive energy. An essential requirement is to understand the energy perceptions and energy acceptance levels of undergraduates who are slated to enter society and make selection decisions by themselves. To educate students on energy perceptions and acceptance levels, a necessary task is to investigate the influencing factors of these phenomena. Hence, to empirically characterize the risk and benefit perceptions of undergraduates in connection to power sources and energy acceptance levels, this research employed ordinary least squares (OLS) regression models, whereby the dependent variables were risk and benefit perceptions for the first hypothesis and energy acceptance for the second hypothesis. The perception regression model was specified as follows:

$$
E P_{i j}=\alpha_{0 j}+H_{i j} \alpha_{1 j}+K_{i j} \alpha_{2 j}+E_{i j} \alpha_{3 j}+T_{i j} \alpha_{4 j}+\varepsilon_{i j}
$$

where $i$ represents a subject's ID (i.e., 1 to 216 ); $j$ represents an energy source; $E P_{i j}$ is the dependent variable for energy or benefit perception; $H_{i j}$ is an individual-level vector of variables such as age, gender, affiliation, and hometown in 2019; $K_{i j}$ denotes knowledge of a specific energy source; $E_{i j}$ refers to an individual's experience; $T_{i j}$ is the individual's trust in a given power generation approach; $\varepsilon_{i j}$ is a normally distributed error term; $\alpha_{0 j}$ is the intercept; $\alpha_{1 j}$ stands for the vector; and $\alpha_{k j}$ are scalars for $k=2, \ldots, 4$, which are the vectors of unknown parameters associated with the $H_{i j}, K_{i j}, E_{i j}$, and $T_{i j}$ to be estimated.

To estimate Hypothesis 2, the energy acceptance regression model was specified thus:

$$
E A_{i j}=\beta_{0 j}+H_{i j} \beta_{1 j}+R P_{i j} \beta_{2 j}+B P_{i j} \beta_{3 j}+\varepsilon_{i j}
$$


where $E A_{i j}$ represents an individual's acceptance of a given energy generation method; $R P_{i j}$ and $B P_{i j}$ represent the individual's risk and benefit perceptions, respectively; $\beta_{0 j}$ denotes the intercept; $\beta_{1 j}$ is the vector; and $\beta_{n j}$ are scalars for $n=2,3$, which are the vectors of unknown parameters associated with the $H_{i j}, R P_{i j}$, and $B P_{i j}$ to be estimated.

Under the OLS assumptions, all the dependent variables were normally distributed. In the OLS regression, estimates in the perception and acceptance models were calculated via maximum likelihood methods, enabling us to compute a marginal change in the dependent variables with a one-unit increase in an independent variable, with all other variables fixed.

The data were examined, and the internal consistency of the scales, which were used to measure all scale variables, were tested on the basis of Cronbach's alpha values. Such values exceeded 0.7 , indicating the reliability of the survey data.

\section{Discussion}

\subsection{Correlation Results}

Tables 5 and 6 summarize the correlations among all the examined variables. Correlation analyses are commonly based on Pearson's $r$ when variables are normally distributed [71]; otherwise, Spearman's $p$ is used [72]. Initial Kolmogorov-Smirnov tests revealed that this study's variables were normally distributed [73], thus compelling the use of Pearson's $r$.

\subsubsection{Knowledge, Experience, Trust, and Risk and Benefit Perceptions}

A striking result is the strong correlation of knowledge with risk and benefit perceptions. In particular, knowledge showed a significantly positive correlation with the perception of benefits from all energy sources at the $1 \%$ level. Knowledge also induced the highest positive risk perception $\left(r=0.155^{* * *}, p=0.004\right)$ and benefit perception $\left(r=0.393^{* * *}\right.$, $p=0.000)$ with respect to nuclear power. This finding indicates that knowledge of nuclear power increases both the risk and benefit perceptions of students, consistent with the characteristics of nuclear power. Nuclear power is recognized as engendering substantial benefits for society, such as $\mathrm{CO}_{2}$ reduction, but it is also a threat to society due to enormous damage if an explosion accident happens. No significant correlations were found between knowledge and risk perception connected to LNG and petroleum. Even though LNG-based electricity accounts for a considerable percentage of power generation in Japan, the students' knowledge of LNG was the lowest (mean $=2.375, \mathrm{SD}=1.062$ ). This may have led to their nonsignificant risk perception regarding this mode of production. Similar to LNG knowledge, that of petroleum power was low (mean $=2.701$, SD $=0.984$ ), which could also explain why risk perception was not significantly related to knowledge.

The correlation between experience and risk perception was significantly positive for hydropower, solar and nuclear power, and petroleum, but the correlation between experience and benefit perception was nonsignificant for these energy sources. In particular, experience was strongly correlated with risk perception involving nuclear power $\left(r=0.278^{* * *}, p=0.000\right)$, with the students having experienced this mode of power generation exhibiting a low perception of risk. As shown in Table 4, for example, two questions were set: experiences of internship in power plants and working experiences in power plants from friends and family members $(1=$ yes, $2=$ no). The values of experience were 1.941 for nuclear power and 1.977 for petroleum power, meaning that the students who had experience with the examined power sources were, at most, $3 \%$. These significantly positive correlations with such a small percentage of experienced people imply that additional information obtained through experience contributes to reductions in risk perception. These findings did not hold for coal and LNG. For coal, the correlation between experience and risk perception was nonsignificant $(r=0.075)$, but its correlation with benefit perception was significant $\left(r=0.144^{* * *}, p=0.006\right)$. This result indicates that students with experience have a significantly low benefit perception. Possibly, the additional information on coal and LNG obtained through experience differs from that derived on nuclear and petroleum power. 
Table 5. Correlation coefficients (Pearson's) with risk and benefit perceptions as the dependent variables.

\begin{tabular}{|c|c|c|c|c|c|c|c|c|c|c|c|c|}
\hline . & \multicolumn{2}{|c|}{ LNG } & \multicolumn{2}{|c|}{ Coal } & \multicolumn{2}{|c|}{ Hydropower } & \multicolumn{2}{|c|}{ Solar } & \multicolumn{2}{|c|}{ Nuclear } & \multicolumn{2}{|c|}{ Petroleum } \\
\hline & $\mathbf{R P}$ & BP & $\mathbf{R P}$ & BP & $\mathbf{R P}$ & BP & $\mathbf{R P}$ & BP & $\mathbf{R P}$ & BP & $\mathbf{R P}$ & BP \\
\hline $\operatorname{Age}^{4}(p$-value $)$ & 0.014 & -0.042 & 0.036 & 0.031 & $\begin{array}{l}0.091 * \\
(0.090)\end{array}$ & 0.008 & $\begin{array}{l}0.091 * \\
(0.091)\end{array}$ & -0.035 & 0.046 & $\begin{array}{l}0.119 * * \\
(0.027)\end{array}$ & 0.001 & -0.033 \\
\hline $\begin{array}{c}\text { Gender } \\
(1=\text { male, } 2=\text { female }) \\
\text { Hometown }\end{array}$ & $\begin{array}{l}0.105^{* *} \\
(0.048)\end{array}$ & -0.025 & $\begin{array}{l}0.175^{* * *} \\
(0.001)\end{array}$ & -0.036 & $\begin{array}{l}0.099^{*} \\
(0.065)\end{array}$ & -0.081 & $\begin{array}{l}0.135^{* *} \\
(0.012)\end{array}$ & -0.018 & $\begin{array}{l}0.144 * * * \\
(0.007)\end{array}$ & $\begin{array}{l}-0.1322^{* *} \\
(0.014)\end{array}$ & 0.081 & $\begin{array}{c}-0.138 * * * \\
(0.009)\end{array}$ \\
\hline $\begin{array}{l}(1=\text { Fukushima and neighboring prefectures, } \\
2=\text { other prefectures })\end{array}$ & 0.005 & 0.067 & 0.001 & -0.008 & -0.001 & 0.055 & -0.068 & 0.019 & -0.013 & 0.022 & 0.004 & 0.039 \\
\hline Grade & 0.000 & -0.067 & -0.022 & 0.075 & 0.037 & 0.055 & 0.097 & 0.024 & 0.045 & 0.025 & -0.058 & -0.040 \\
\hline $\begin{array}{c}\text { Affiliation } \\
(1=\text { science and engineering, } 2=\text { social science })\end{array}$ & -0.008 & 0.053 & -0.058 & 0.052 & 0.037 & 0.077 & 0.061 & 0.050 & $\begin{array}{c}-0.111^{* *} \\
(0.038)\end{array}$ & 0.072 & -0.041 & $\begin{array}{l}0.099^{*} \\
(0.064)\end{array}$ \\
\hline${ }^{2} \mathrm{~K}_{\mathrm{LNG}}$ & 0.021 & $\begin{array}{c}0.170^{* * *} \\
(0.001)\end{array}$ & & & & & & & & & & \\
\hline${ }^{3} E_{\mathrm{LNG}}$ & 0.028 & 0.052 & & & & & & & & & & \\
\hline${ }^{4} \mathrm{~T}_{\mathrm{LNG}}$ & 0.010 & $\begin{array}{c}0.141^{* * *} \\
(0.008)\end{array}$ & & & & & & & & & & \\
\hline $\mathrm{K}_{\text {Coal }}$ & & & $\begin{array}{l}0.136 * * \\
(0.010)\end{array}$ & $\begin{array}{c}0.304 * * * \\
(0.000)\end{array}$ & & & & & & & & \\
\hline $\mathrm{E}_{\text {Coal }}$ & & & 0.075 & $\begin{array}{c}0.144^{* * *} \\
(0.006)\end{array}$ & & & & & & & & \\
\hline $\mathrm{T}_{\text {Coal }}$ & & & 0.056 & $\begin{array}{c}0.220 * * * \\
(0.000)\end{array}$ & & & & & & & & \\
\hline $\mathrm{K}_{\text {Hydropower }}$ & & & & & $\begin{array}{l}0.118^{* *} \\
(0.118)\end{array}$ & $\begin{array}{c}0.309 * * * \\
(0.000)\end{array}$ & & & & & & \\
\hline $\mathrm{T}_{\text {Hydropower }}$ & & & & & $\begin{array}{l}0.104^{*} \\
(0.055)\end{array}$ & $\begin{array}{c}0.291 * * * \\
(0.000)\end{array}$ & & & & & & \\
\hline $\mathrm{K}_{\text {Solar }}$ & & & & & & & $\begin{array}{l}0.109^{* *} \\
(0.045)\end{array}$ & $\begin{array}{c}0.310 * * * \\
(0.000)\end{array}$ & & & & \\
\hline$E_{\text {Solar }}$ & & & & & & & $\begin{array}{l}0.107^{* *} \\
(0.047)\end{array}$ & 0.044 & & & & \\
\hline $\mathrm{T}_{\text {Solar }}$ & & & & & & & $\begin{array}{l}0.132^{* *} \\
(0.014)\end{array}$ & $\begin{array}{c}0.197 * * * \\
(0.000)\end{array}$ & & & & \\
\hline $\mathrm{K}_{\text {Nuclear }}$ & & & & & & & & & $\begin{array}{l}0.155^{* * *} \\
(0.004)\end{array}$ & $\begin{array}{c}0.393 * * * \\
(0.000)\end{array}$ & & \\
\hline $\mathrm{E}_{\text {Nulclear }}$ & & & & & & & & & $\begin{array}{c}0.278^{* * *} \\
(0.000)\end{array}$ & 0.081 & & \\
\hline $\mathrm{T}_{\text {Nuclear }}$ & & & & & & & & & $\begin{array}{l}-0.242 * * * \\
(0.000)\end{array}$ & $\begin{array}{l}0.150^{* * *} \\
(0.005)\end{array}$ & & \\
\hline $\mathrm{K}_{\text {Petroleum }}$ & & & & & & & & & & & 0.032 & $\begin{array}{c}0.193 * * * \\
(0.000)\end{array}$ \\
\hline $\mathrm{E}_{\text {Petroleum }}$ & & & & & & & & & & & $\begin{array}{c}0.214^{* * *} \\
(0.000)\end{array}$ & 0.016 \\
\hline $\mathrm{T}_{\text {Petroleum }}$ & & & & & & & & & & & 0.035 & $\begin{array}{l}0.091 * \\
(0.087)\end{array}$ \\
\hline
\end{tabular}

*** Significant at the $1 \%$ level, ${ }^{* *}$ at the $5 \%$ level, and $*$ at the $10 \%$ level $;{ }^{2} \mathrm{~K}$ : knowledge, ${ }^{3} \mathrm{E}$ : experience, ${ }^{4} \mathrm{~T}$ : trust,${ }^{4} p$-value in parentheses. 
Table 6. Correlation coefficients (Pearson's) with acceptance as the dependent variable.

\begin{tabular}{|c|c|c|c|c|c|c|}
\hline & Acceptancy LNG & Acceptancy Coal & Acceptancy Hydropower & Acceptancy Solar & Acceptancy Nuclear & Acceptancy Petroleum \\
\hline Age & 0.008 & 0.040 & 0.105 & 0.038 & 0.105 & -0.024 \\
\hline Gender $(1=\text { male, } 2=\text { female })^{1}(p$-value $)$ & -0.014 & 0.038 & -0.056 & 0.004 & $-0.173^{* * *}(0.002)$ & $-0.113^{* *}(0.036)$ \\
\hline $\begin{array}{c}\text { Hometown } \\
(1=\text { Fukushima and neighbor } \\
\text { prefectures, } 2=\text { other prefectures })\end{array}$ & $0.142^{* * *}(0.009)$ & 0.032 & 0.056 & -0.058 & 0.065 & $0.129 * *(0.017)$ \\
\hline Grade & 0.048 & 0.050 & $0.154^{* * *}(0.006)$ & 0.032 & 0.055 & -0.018 \\
\hline $\begin{array}{c}\text { Affiliation } \\
(1=\text { science and engineering, } \\
2=\text { social science })\end{array}$ & -0.028 & -0.014 & -0.012 & -0.053 & $0.150^{* * *}(0.008)$ & 0.069 \\
\hline $\mathrm{RP}_{\mathrm{LNG}}$ & $-0.128 * *(0.018)$ & & & & & \\
\hline $\mathrm{BP}_{\mathrm{LNG}}$ & $0.301 * * *(0.000)$ & & & & & \\
\hline $\mathrm{RP}_{\text {Coal }}$ & & $-0.187^{* * *}(0.001)$ & & & & \\
\hline B PCoal & & 0.103 & & & & \\
\hline $\mathrm{RP}_{\text {Hydropower }}$ & & & -0.029 & & & \\
\hline $\mathrm{BP}_{\text {Hydropower }}$ & & & $0.266^{* * *}(0.000)$ & & & \\
\hline $\mathrm{RP}_{\text {Solar }}$ & & & & 0.086 & & \\
\hline $\mathrm{BP}_{\text {Solar }}$ & & & & $0.431^{* * *}(0.000)$ & & \\
\hline $\mathrm{RP}_{\text {Nuclear }}$ & & & & & $\begin{array}{c}-0.351^{* * *} \\
(0.000)\end{array}$ & \\
\hline $\mathrm{BP}_{\text {Nuclear }}$ & & & & & $0.252^{* * *}(0.000)$ & \\
\hline $\mathrm{RP}_{\text {Petroleum }}$ & & & & & & $-0.166^{* * *}$ \\
\hline $\mathrm{BP}_{\text {Petroleum }}$ & & & & & & $0.131 * *(0.015)$ \\
\hline
\end{tabular}


Trust in government and power operation organizations, generally, had a positively significant correlation with benefit perception (LNG: $r=0.141^{* * *}, p=0.008$; coal: $r=0.220^{* * *}, p=0.000$; hydropower: $r=0.291^{* * *}, p=0.000$; solar: $r=0.197^{* * *}, p=0.000$; nuclear: $r=0.150^{* * *}, p=0.000$; petroleum: $r=0.099^{*}, p=0.064$ ). However, it was also negatively and significantly correlated with risk perception toward nuclear power generation $\left(r=-0.242^{* * *}, p=0.000\right)$. This finding can be explained by the adverse effects of the nuclear power explosion in Fukushima Prefecture.

\subsubsection{Risk and Benefit Perceptions and Energy Acceptance}

On the basis of the results summarized in Table 6, two interesting insights were obtained with regard to demographic factors. The first is that the female students registered a lower acceptance of nuclear $\left(r=-0.173^{* * *}, p=0.002\right)$ and petroleum $\left(r=-0.113^{* *}\right.$, $p=0.036$ ) power generation than that exhibited by the male students. The second is that the students hailing from Fukushima Prefecture and its neighboring districts showed a lower acceptance of LNG and petroleum power generation than that shown by the students from other prefectures. The risk perception of the students was significantly and negatively correlated with the acceptance of all traditional energy sources and nuclear power, but it was not significantly correlated with renewable energy (hydropower and solar). This finding can be explained by the fact that the risks perceived by the students with respect to traditional and nuclear energy generation predicted their acceptance, whereas the risks discerned in relation to renewable energy did not. This result is the first to be derived in connection to the comparison of risk perceptions regarding renewable and traditional energy. Conversely, benefit perception significantly and positively correlated with the acceptance of energy sources, except coal. This may be explained by the air pollution issue, particularly the air pollution situation in China, which has reduced the benefit of coal-based power generation from the students' perspectives.

\subsection{Regression Analysis Results for Hypothesis 1 (Dependent Variables: Risk and Benefit Perceptions)}

Figure 6 illustrates the marginal effects of the independent variables on the students' risk and benefit perceptions regarding the main energy generation sources in Japan. Interestingly, gender significantly predicted the risk perception toward power generation for most of the energy sources, but it was a nonsignificant factor in predicting benefit perception. This result indicates that female students have a higher risk perception than male students, consistent with the findings of previous risk perception studies [74]. A higher year level also significantly lowered the risk perception toward petroleum and significantly increased the benefit perception toward hydropower.

We examined how knowledge, experience, and trust can predict students' risk and benefit perceptions. The results showed that knowledge positively affected the respondents' risk perception toward coal, solar, and nuclear power, implying that as knowledge of various power generation methods increases, so does the risk perception of students. In particular, the risk perception toward coal and nuclear power was at the $1 \%$ significance level. This view of coal and nuclear power generation can be explained by adverse air pollution and $\mathrm{CO}_{2}$ effects and the Fukushima nuclear accident, respectively. Knowledge also more significantly affected benefit perception than risk perception. Finally, knowledge predicted the benefit perception toward most of the energy sources at the $1 \%$ significance level (LNG at the 5\% significance level) (Figure 6). In other words, energy knowledge more considerably increased the students' benefit perception than risk perception.

Mixed results were derived as to the influence of experience on the different energy sources. First, it significantly predicted the risk perception of nuclear power, hydropower, and solar power generation. The students with experience of these energy sources had low risk perception toward nuclear power; however, intriguingly, experience imposed the same influence on renewable energy. Second, experience significantly predicted only the benefit perception toward coal power generation; the opposite was found with respect to the three aforementioned energy sources. The students with experience of coal power generation 
had a low benefit perception of this production mode. Students are expected to obtain extra information through experience gained via visits and internships in power plants or from friends or relatives who have worked in these facilities. This additional information worked "constructively" for nuclear power, hydropower, and solar power generation but "unconstructively" for coal power generation.

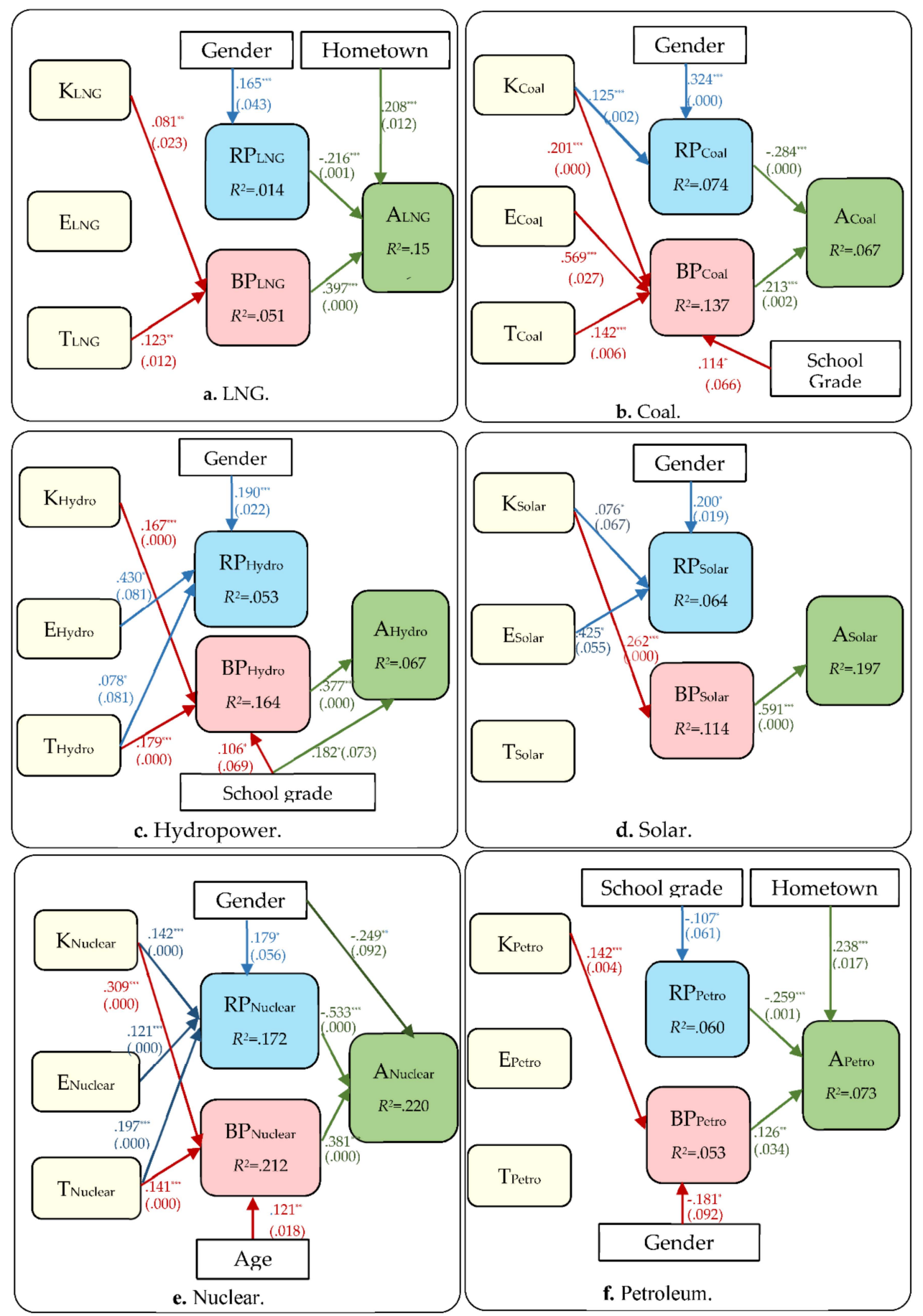

Figure 6. Regression. ${ }^{1} p$-value in parentheses, ${ }^{* * *}$ Significant at the $1 \%$ level, ${ }^{* *}$ at the $5 \%$ level, and * at the $10 \%$ level. 
Trust in government and power company operation negatively affected the risk perception toward nuclear power at the $1 \%$ significance level. As previously explained, the less trust the students had, the higher the risk perception generated-A tendency attributed to the nuclear accident. Trust more strongly predicted benefit perception than risk perception. As indicated in Figure $6 \mathrm{a}-\mathrm{c}, \mathrm{e}$, greater trust showed a more positive relationship with the benefit perception toward LNG, coal, hydropower, and nuclear power generation, with significance at the $1 \%$ level for the last three sources.

\subsection{Regression Analysis Results for Hypothesis 1 (Dependent Variables: Risk and Benefit Perceptions)}

An interesting finding is that hometown location had a positively significant effect on the acceptance of LNG- and petroleum-based power generation, revealing that students who came from Fukushima Prefecture or neighboring districts were less willing to accept these energy sources than the students hailing from the other prefectures. This finding may be explained by the fact that, when the students had an unclear understanding of the adverse effects of LNG and petroleum, they did not want to take the risk of accepting these energy sources.

The students' benefit perception more strongly explained energy acceptance than risk perception. Risk perception negatively predicted the acceptance of LNG, coal, nuclear power, and petroleum at the $1 \%$ significance level, but it was not a significant factor for renewable energy, hydropower, and solar energy. These results reflect that students do not fully acknowledge the disadvantages of renewable energy. At the same time, benefit perception significantly predicted the acceptance of all the examined power generation modes, indicating that students' value benefits more than risks when choosing energy sources.

\subsection{Energy Categorization Based on Results}

With the results in Figure 6 as grounding and the relationships among the students' knowledge, experience, trust, risk and benefit perceptions, and acceptance, we classified the examined energy sources into three categories (Table 7). The first category is LNG and petroleum (Figure 6a,f), for which the students' knowledge levels were the lowest. This insufficient knowledge could be the reason why the influencing factors minimally affected the students' risk and benefit perceptions. Furthermore, although the students' risk and benefit perceptions negatively and positively predicted acceptance, respectively, there is the possibility that the results may not accurately reflect reality because the students may not have correctly understood the risk- and benefit-related determinants. We call this classification "obscure energy."

Table 7. Categorization of energy types.

\begin{tabular}{|c|c|c|}
\hline Energy Classification & Energy Source & Characteristics \\
\hline Blind & LNG, petroleum & $\begin{array}{l}\text { - Insufficient knowledge } \\
\text { - } \quad \text { Only knowledge affected benefit perception } \\
\text { - } \quad \text { No influencing factors predicted risk perception } \\
\text { - Students who came from other prefectures (not } \\
\text { Fukushima and its neighboring prefectures) had } \\
\text { high acceptance levels }\end{array}$ \\
\hline Well- known & Coal, nuclear & $\begin{array}{l}\text { Influencing factors (knowledge, experience, trust) } \\
\text { significantly affected risk or benefit perception } \\
\text { Risk and benefit perceptions significantly } \\
\text { predicted acceptance }(p<0.01)\end{array}$ \\
\hline Exploratory & Hydropower, solar & $\begin{array}{l}\text { Experience significantly predicted } \\
\text { risk perception } \\
\text { - Only benefit perception predicted acceptance }\end{array}$ \\
\hline
\end{tabular}


The second energy classification comprises coal and nuclear power (Figure 6b,e). Because of the long-term application of these sources, residents interact more extensively with these types of energy in daily life, as can be seen from their availing of these stable power sources, the suffering that they endured because of the nuclear accident, and air pollution. Given these interactions, the students were familiar with the advantages and disadvantages of these energy sources. Therefore, their knowledge, experience, and trust predicted their risk and benefit perceptions with respect to this energy classification. Their perceptions also strongly predicted their acceptance of these energy sources. We refer to the second category as "well-known energy."

The third class of energy sources consists of hydropower and solar power (Figure 6c,d). The results demonstrated that only benefit perception significantly predicted the acceptance of these energy sources, possibly because of their distinguished characteristics. Many of the current energy policies in the world focus on the development of renewable energy, and the education and media domains emphasize the advantages and benefits of such development. The problem is that this emphasis on benefit seemed to have obscured the influence of risk perception on energy acceptance, albeit the risk perception of the students was not necessarily low. Particularly for solar energy, the usage period remains limited. This deficiency may further reduce the influence of risk perception on energy acceptance. We call the third class of sources "exploratory energy."

The classification of energy sources on the basis of students' knowledge, experience, trust, risk and benefit perceptions, and energy acceptance is a first in energy studies.

\section{Conclusions and Policy Implications}

This study analyzed the determinants of students' risk and benefit perceptions regarding the main energy generation sources in Japan and their acceptance of these sources. Gender predicted the risk perception of most of the energy sources examined, except petroleum. Knowledge was a significant predictor of the risk perception toward coal, nuclear, and solar power generation. Experience explained the risk perception toward hydropower, solar power, and nuclear power at a significant level, while trust had no effect on risk perception, except with respect to nuclear power generation. Knowledge significantly predicted the students' benefit perception of all the kinds of power generation modes, but experience accounted for only the benefit perception toward coal power generation. Trust was much more powerful in predicting benefit perception than risk perception. It is an important factor that affects the likelihood of benefit perception regarding LNG, coal, hydropower, and nuclear power. These findings represent new contributions to the literature, as few studies have empirically examined the influencing factors of risk and benefit perceptions toward various power generation approaches. With the results as reference, as well, we inquired into the various energy acceptance levels determined by risk and benefit perceptions. We illustrated that the students' benefit perception more strongly explained energy acceptance than risk perception. Moreover, the results involving the hypotheses enabled us to classify the energy sources into blind (LNG and petroleum), well-known (coal and nuclear), and exploratory (hydropower and solar) energy. These results not only expand important dimensions of research on energy acceptance but also reveal the important roles of risk and benefit perceptions in energy acceptance in the real world. This study is also the first to classify energy sources on the grounds of students knowledge, experience, trust, risk and benefit perceptions, and energy acceptance. This classification is expected to contribute to the design of energy education programs to fulfil the university social responsibility.

Overall, the students' knowledge, experience, and trust more strongly predicted benefit perception than risk perception. Although both risk and benefit perceptions were important predictors of energy acceptance, the students' benefit perception more considerably affected acceptance. This result can be explained by three issues. First, most of the knowledge regarding various energy resources that the students obtained were advantages, particularly for renewable energy. Because the students had more experience 
and knowledge of coal and nuclear power, their risk perception regarding these types of energy was higher than that toward the other sources. However, the students still perceived substantial benefits from coal and nuclear power. Second, the usage period affected the students' perceptions. Because the application of renewable energy is in its infancy compared with traditional energy and because the government promotes this source to reduce the greenhouse effect, the students with less experience of renewable energy perceived high benefits from this energy source and exhibited considerable acceptance of it. Meanwhile, coal power, which has seen long-standing application, and nuclear power, which caused accidents, were seen as having both benefits and adverse effects on people's lives. It was easier for the students to judge the risks and benefits and whether to accept these technologies.

The key findings can guide the effective design and implementation of public policy interventions intended for intention and behavioral change in the energy education context in Japan and elsewhere. Although we do not discount the effects of local culture on shaping energy-related perceptions [75], the difference between the factors influencing risk and benefit perceptions and energy acceptance prevailed to a sufficient extent for us to assume a minimized probability of its being unique to Japanese students. Thus, lessons learned from the situation of Japanese students' may inform education programs and policies for intention and behavioral change intervention among other learners in other regions. Second, the results provide new evidence of the importance of energy knowledge in students' energy-related risk and benefit perceptions, which influence their energy acceptance levels. Students absorb energy knowledge primarily through the media, the Internet, and experience, among other sources. Given that the advantages and disadvantages of each energy type are incompletely reviewed, students have a biased judgment toward some energy sources. Thus, we suggest that energy education be introduced into undergraduate courses to broaden students' knowledge and strengthen their awareness of the merits and drawbacks of energy sources from economic, environmental, energy efficiency, and energy safety perspectives. In addition, students should accumulate experiences of visiting power plants for them to understand the energy situation; this can also be beneficial in the energy choices that they make later in life. Trust in government and power plants has become essential, particularly after the occurrence of nuclear accidents. Therefore, to reduce students' risk perception and build a trusting relationship, the government and power plants should provide safe and stable services. Once trust is destroyed, it is difficult to recover. Furthermore, benefit perception more strongly predicted energy acceptance than risk perception, thus highlighting the need to increase the benefits of power generation, which will accordingly enhance students' energy acceptance. We recommend that power plants consider providing low prices, protecting the environment, and ensuring a safe and stable power supply for residents. Because it is difficult for a given energy source to satisfy all standards of benefit creation, multiple energy resources can be introduced on the basis of local characteristics. This strategy entails cooperation among various power plants and can be an important topic in the energy field. Finally, we suggest that education programs be designed on the grounds of blind, well-known, and exploratory energy, with education plans organized on the basis of the characteristics of each classification.

Overall, this study presented crucial findings for decision makers regarding energy education in undergraduate programs. These insights include what factors influence undergraduates' energy perceptions and how their energy acceptance can be increased. We believe that our findings make an important contribution to addressing the lack of knowledge regarding the main energy sources currently used in Japan. This research might also serve as an important reference on (1) the influencing factors of students' risk and benefit perceptions toward various energy types; (2) the relationship among risk perception, benefit perception, and energy acceptance; and (3) energy education programs that can later benefit the energy market. 
Similar to other studies, this research is encumbered by certain limitations. Although we tried our best to verify this study in a broad manner by interviewing undergraduate students, having a discussion in class, and conducting a questionnaire survey, there may still be unavoidable and unexpected biases in relation to the results on predicting energy acceptance. Therefore, further research on students' energy acceptance should be developed and conducted, including international comparisons, to confirm the robustness of the results on a wider scale. Such research is crucial to the development of energy education programs in the long run.

Author Contributions: Conceptualization, L.W. and K.W.; methodology, L.W.; software, K.W.; validation, L.W., K.W. and T.W.; formal analysis, K.W.; investigation, L.W. and K.W.; writing-original draft preparation, L.W.; writing-review and editing, L.W. and T.W.; supervision, T.W.; funding acquisition, T.W. All authors have read and agreed to the published version of the manuscript.

Funding: This research was funded by Kochi University of Technology.

Institutional Review Board Statement: Not applicable.

Informed Consent Statement: Informed consent was obtained from all participants involved in the study.

Data Availability Statement: The data presented in this study are available on suitable demand.

Acknowledgments: The authors are grateful for the anonymous referees' constructive comments; the questionnaire respondents from the schools of regional design, agriculture, education, in-ternation, and engineering in Universities; and the third-year civil engineering students at the university who gave constructive comments during the group discussions. We also thank the assistance of language editor.

Conflicts of Interest: The authors declare no conflict of interest.

$\begin{array}{ll}\text { Nomenclature } & \\ \text { Risk perception } & \text { RP } \\ \text { Benefit perception } & \text { BP } \\ \text { Liquid natural gas } & \text { LNG } \\ \text { Feed-in tariff } & \text { FIT } \\ \text { Willingness to pay } & \text { WTP } \\ \text { General electricity utilities } & \text { GEUs } \\ \text { Power producers and suppliers } & \text { PPSs } \\ \text { Contingent valuation } & \text { CV } \\ \text { Energy security, environmental protection, and efficient supply } & \text { 3Es } \\ \text { Economic efficiency, environment, energy security and safety } & \text { 3Es + S } \\ \text { Ministry of Economy, Trade and Industry of Japan } & \text { METI } \\ \text { Greenhouse gas } & \text { GHG } \\ \text { Ordinary least squares } & \text { OLS } \\ \text { Nuclear Regulation Authority } & \text { NRA }\end{array}$

\section{References}

1. Ministry of Economy Trade and Industry. Japan's Energy Problems. 2019. (In Japanese). Available online: https://www.enecho. meti.go.jp/about/special/johoteikyo/energyissue2019.html (accessed on 20 December 2019).

2. Gao, L.; Hiruta, Y.; Ashina, S. Promoting renewable energy through willingness to pay for transition to a low carbon society in Japan. Renew. Energy 2020, 162, 818-830. [CrossRef]

3. Ministry of Economy Trade and Industry. Long-Term Energy Supply/Demand Outlook; Ministry of Economy Trade and Industry: Tokyo, Japan, July 2015. (In Japanese)

4. Japan Climate and Energy Group. Long-Term Scenarios for Decarbonizing Japan. Available online: https:/ /www.wwf.or.jp/ activities/data/170413ExusecutiveSummary_ENG_Final_rev2.pdf (accessed on 10 March 2020).

5. Ministry of Economy Trade and Industry. Japan's Energy 2019-10 Questions for Understanding the Current Energy Situation. Available online: https://www.enecho.meti.go.jp/en/category/brochures/pdf/japan_energy_2019.pdf (accessed on 30 May 2020). 
6. Lesser, J.A.; Su, X. Design of an economically efficient feed-in tariff structure for renewable energy development. Energy Policy 2008, 36, 981-990. [CrossRef]

7. Ministry of Economy Trade and Industry (METI). Energy White Paper 2016; Ministry of Economy Trade and Industry: Tokyo, Japan, 2016.

8. Ministry of Economy Trade and Industry (METI). Strategic Energy Plan 2014a; Ministry of Economy Trade and Industry: Tokyo, Japan, 2014.

9. Enerugi Kankyo Kaigi (Energy and Environment Ministerial Committee). Available online: https://www.cas.go.jp/jp/seisaku/ npu/policy09/archive01.html (accessed on 3 April 2020).

10. Watanabe, R. After the Fukushima disaster: Japan's nuclear policy change from 2011 to 2012. Rev. Policy Res. 2016, 33, 623-645. [CrossRef]

11. Takao, Y. Japan's Environmental Politics and Governance: From Trading Nation to EcoNation; Taylor \& Francis: Abingdon, UK, 2016; ISBN 1317517784.

12. Osamu Tsukimori, K.H. Interview-Tokyo Gas Aims to Lift Share of Retail Power Market. Available online: https://www. reuters.com/article/japan-tokyo-gas-president/interview-tokyo-gas-aims-to-lift-share-of-retail-power-marketidUKL4N0 MS07B20140331 (accessed on 9 September 2020).

13. Valentine, S.; Sovacool, B. Energy transitions and mass publics: Manipulating public perception and ideological entrenchment in Japanese nuclear power policy. Renew. Sustain. Energy Rev. 2019, 101, 295-304. [CrossRef]

14. Electricity and Gas Market Surveillance Commission (EGMSC). Electricity Market Transactions Report; Electricity and Gas Market Surveillance Commission: Tokyo, Japan, 2016.

15. Znalytics Focus: Japan's Competitive Landscape-Retail Energy Market Survey Reveals Helpful Insights. Available online: https:// znalytics.com/2017-6-16-focus-japans-competitive-landscape-retail-energy-market-survey-reveals-helpful-insights / (accessed on 1 April 2020).

16. Hite, D.; Duffy, P.; Bransby, D.; Slaton, C. Consumer willingness-to-pay for biopower: Results from focus groups. Biomass Bioenergy 2008, 32, 11-17. [CrossRef]

17. Mozumder, P.; Vásquez, W.F.; Marathe, A. Consumers' preference for renewable energy in the southwest USA. Energy Econ. 2011, 33, 1119-1126. [CrossRef]

18. Nomura, N. Willingness to pay for environmental sound energy systems. J. Jpn. Inst. Energy 2009, 88, 140-146. [CrossRef]

19. Whitehead, J.C.; Cherry, T.L. Willingness to pay for a green energy program: A comparison of ex-ante and ex-post hypothetical bias mitigation approaches. Resour. Energy Econ. 2007, 29, 247-261. [CrossRef]

20. Komarek, T.M.; Lupi, F.; Kaplowitz, M.D. Valuing energy policy attributes for environmental management: Choice experiment evidence from a research institution. Energy Policy 2011, 39, 5105-5115. [CrossRef]

21. Cicia, G.; Cembalo, L.; del Giudice, T.; Palladino, A. Fossil energy versus nuclear, wind, solar and agricultural biomass: Insights from an Italian national survey. Energy Policy 2012, 42, 59-66. [CrossRef]

22. El-Sayed, M.A.H.; Kreusel, J. Substitution potential of solar thermal power stations in electrical energy systems. Renew. Energy 1995, 6, 849-854. [CrossRef]

23. Jaber, J.O. Future energy consumption and greenhouse gas emissions in Jordanian industries. Appl. Energy 2002, 71, 15-30. [CrossRef]

24. Al-Ghandoor, A.; Al-Hinti, I.; Jaber, J.O.; Sawalha, S.A. Electricity consumption and associated GHG emissions of the Jordanian industrial sector: Empirical analysis and future projection. Energy Policy 2008, 36, 258-267. [CrossRef]

25. Yazdanpanah, M.; Komendantova, N.; Ardestani, R.S. Governance of energy transition in Iran: Investigating public acceptance and willingness to use renewable energy sources through socio-psychological model. Renew. Sustain. Energy Rev. 2015, 45, 565-573. [CrossRef]

26. Ho, S.S.; Oshita, T.; Looi, J.; Leong, A.D.; Chuah, A.S.F. Exploring public perceptions of benefits and risks, trust, and acceptance of nuclear energy in Thailand and Vietnam: A qualitative approach. Energy Policy 2019, 127, 259-268. [CrossRef]

27. Wang, S.; Wang, J.; Lin, S.; Li, J. Public perceptions and acceptance of nuclear energy in China: The role of public knowledge, perceived benefit, perceived risk and public engagement. Energy Policy 2019, 126, 352-360. [CrossRef]

28. Meseguer-Sánchez, V.; Abad-Segura, E.; Belmonte-Ureña, L.J.; Molina-Moreno, V. Examining the research evolution on the socio-economic and environmental dimensions on university social responsibility. Int. J. Environ. Res. Public Health 2020, 17, 4729. [CrossRef]

29. Ministry of Economy Trade and Industry (METI). The Strategic Energy Plan of Japan. In Meeting Global Challenges and Securing Energy Futures; Revised in June 2010; Summary; Ministry of Economy Trade and Industry: Tokyo, Japan, 2010.

30. Kuramochi, T. Review of energy and climate policy developments in Japan before and after Fukushima. Renew. Sustain. Energy Rev. 2015, 43, 1320-1332. [CrossRef]

31. Kucharski, J.B.; Unesaki, H. An institutional analysis of the Japanese energy transition. Environ. Innov. Soc. Transit. 2018, 29, 126-143. [CrossRef]

32. 2016a. Japan's Energy Deregulation: Wielding Discounts, New Power Providers Battle for Households. Nikkei Asian Review. 2016. Available online: https:/ / asia.nikkei.com/Business/Wielding-discounts-new-power-providers-battle-for-households (accessed on 7 February 2020).

33. Japanese Utilities: Chugoku Electric to Buy into Malaysian Plant. Nikkei Asian Review. 2016. Available online: https:/ / asia.nikkei.com/Business /Chugoku-Electric-to-buy-into-Malaysian-plant\#: \{\}:text=Chugoku\%20Electric\%20will\%20 purchase $\% 20$ half, aspects $\% 20$ of $\% 20$ coal $\% 2$ Dfired $\% 20$ plants (accessed on 7 February 2020).

34. Agency for Natural Resources and Energy. What has Changed with the Full Liberalization of Electricity Retailing? Agency for Natural Resources and Energy: Tokyo, Japan, 2017. 
35. Iyengar, S. Television news and citizens' explanations of national affairs. Am. Polit. Sci. Rev. 1987, 81, 815-831. [CrossRef]

36. Lowi, T. The End of Liberalism; Norton: New York, NY, USA, 1969.

37. Chen, M.-F.; Lin, Y.-P.; Cheng, T.-J. Public attitudes toward nanotechnology applications in Taiwan. Technovation 2013, 33, 88-96. [CrossRef]

38. McGowan, F; Sauter, R. Public Opinion on Energy Research: A Desk Study for the Research Councils; University of Sussex: Brighton, UK, 2005.

39. Molin, E. Causal analysis of hydrogen acceptance. Transp. Res. Rec. 2005, 1941, 115-121. [CrossRef]

40. Zografakis, N.; Sifaki, E.; Pagalou, M.; Nikitaki, G.; Psarakis, V.; Tsagarakis, K.P. Assessment of public acceptance and willingness to pay for renewable energy sources in Crete. Renew. Sustain. Energy Rev. 2010, 14, 1088-1095. [CrossRef]

41. Fischhoff, B.; Slovic, P.; Lichtenstein, S.; Read, S.; Combs, B. How safe is safe enough? A psychometric study of attitudes towards technological risks and benefits. Policy Sci. 1978, 9, 127-152. [CrossRef]

42. Mumpower, J.L.; Shi, L.; Stoutenborough, J.W.; Vedlitz, A. Psychometric and demographic predictors of the perceived risk of terrorist threats and the willingness to pay for terrorism risk management programs. Risk Anal. 2013, 33, 1802-1811. [CrossRef] [PubMed]

43. Earle, T.C. Trust, risk perception and the TCC model of cooperation. In Trust in Cooperative Risk Management: Uncertainty Over Skepticism in the Public Mind; Siegrist, M., Earle, T.C., Gutscher, H., Eds.; Earthscan: London, UK, 2010; pp. 1-49.

44. Morgan, M.G.; Fischhoff, B.; Bostrom, A.; Atman, C.J. Risk Communication: A Mental Models Approach; Cambridge University Press: Cambridge, UK, 2002; ISBN 0521802237.

45. Stoutenborough, J.W.; Vedlitz, A. The role of scientific knowledge in the public's perceptions of energy technology risks. Energy Policy 2016, 96, 206-216. [CrossRef]

46. Siegrist, M. A causal model explaining the perception and acceptance of gene technology. J. Appl. Soc. Psychol. 1999, 29, 2093-2106. [CrossRef]

47. Siegrist, M. The influence of trust and perceptions of risks and benefits on the acceptance of gene technology. Risk Anal. 2000, 20, 195-203. [CrossRef] [PubMed]

48. Siegrist, M.; Cvetkovich, G. Perception of hazards: The role of social trust and knowledge. Risk Anal. 2000, 20, 713-720. [CrossRef]

49. Finucane, M.L.; Alhakami, A.; Slovic, P.; Johnson, S.M. The affect heuristic in judgments of risks and benefits. J. Behav. Decis. Mak. 2000, 13, 1-17. [CrossRef]

50. Midden, C.J.H.; Huijts, N.M.A. The role of trust in the affective evaluation of novel risks: The case of CO2 storage. Risk Anal. An Int. J. 2009, 29, 743-751. [CrossRef] [PubMed]

51. Montijn-Dorgelo, F.N.H.; Midden, C.J.H. The role of negative associations and trust in risk perception of new hydrogen systems. J. Risk Res. 2008, 11, 659-671. [CrossRef]

52. Siegrist, M.; Cousin, M.-E.; Kastenholz, H.; Wiek, A. Public acceptance of nanotechnology foods and food packaging: The influence of affect and trust. Appetite 2007, 49, 459-466. [CrossRef]

53. Batley, S.L.; Fleming, P.D.; Urwin, P. Willingness to pay for renewable energy: Implications for UK green tariff offerings. Indoor Built Environ. 2000, 9, 157-170. [CrossRef]

54. Ruin, I.; Gaillard, J.-C.; Lutoff, C. How to get there? Assessing motorists' flash flood risk perception on daily itineraries. Environ. Hazards 2007, 7, 235-244. [CrossRef]

55. Paton, D.; Smith, L.; Daly, M.; Johnston, D. Risk perception and volcanic hazard mitigation: Individual and social perspectives. J. Volcanol. Geotherm. Res. 2008, 172, 179-188. [CrossRef]

56. Siegrist, M.; Gutscher, H. Flooding risks: A comparison of lay people's perceptions and expert's assessments in Switzerland. Risk Anal. 2006, 26, 971-979. [CrossRef]

57. Ho, M.; Shaw, D.; Lin, S.; Chiu, Y. How do disaster characteristics influence risk perception? Risk Anal. An Int. J. 2008, 28, 635-643. [CrossRef] [PubMed]

58. Scolobig, A.; de Marchi, B.; Borga, M. The missing link between flood risk awareness and preparedness: Findings from case studies in an Alpine Region. Nat. Hazards 2012, 63, 499-520. [CrossRef]

59. Murakami, K.; Ida, T.; Tanaka, M.; Friedman, L. Consumers ' willingness to pay for renewable and nuclear energy: A comparative analysis between the US and Japan. Energy Econ. 2015, 50, 178-189. [CrossRef]

60. Kim, Y.; Kim, W.; Kim, M. An international comparative analysis of public acceptance of nuclear energy. Energy Policy 2014, 66, 475-483. [CrossRef]

61. Siegrist, M. Factors influencing public acceptance of innovative food technologies and products. Trends Food Sci. Technol. 2008, 19, 603-608. [CrossRef]

62. Huijts, N.M.A.; Molin, E.J.E.; Steg, L. Psychological factors influencing sustainable energy technology acceptance: A review-based comprehensive framework. Renew. Sustain. Energy Rev. 2012, 16, 525-531. [CrossRef]

63. Pidgeon, N.F.; Lorenzoni, I.; Poortinga, W. Climate change or nuclear power-No thanks! A quantitative study of public perceptions and risk framing in Britain. Glob. Environ. Chang. 2008, 18, 69-85. [CrossRef]

64. Wolsink, M. Contested environmental policy infrastructure: Socio-political acceptance of renewable energy, water, and waste facilities. Environ. Impact Assess. Rev. 2010, 30, 302-311. [CrossRef]

65. Tanaka, Y. Major psychological factors determining public acceptance of the siting of nuclear facilities. J. Appl. Soc. Psychol. 2004, 34, 1147-1165. [CrossRef]

66. De Groot, J.I.M.; Steg, L. Morality and nuclear energy: Perceptions of risks and benefits, personal norms, and willingness to take action related to nuclear energy. Risk Anal. An Int. J. 2010, 30, 1363-1373. [CrossRef]

67. Visschers, V.H.M.; Keller, C.; Siegrist, M. Climate change benefits and energy supply benefits as determinants of acceptance of nuclear power stations: Investigating an explanatory model. Energy Policy 2011, 39, 3621-3629. [CrossRef] 
68. Prati, G.; Zani, B. The effect of the Fukushima nuclear accident on risk perception, antinuclear behavioral intentions, attitude, trust, environmental beliefs, and values. Environ. Behav. 2013, 45, 782-798. [CrossRef]

69. Park, E.; Ohm, J.Y. Factors influencing the public intention to use renewable energy technologies in South Korea: Effects of the fukushima nuclear accident. Energy Policy 2014, 65, 198-211. [CrossRef]

70. ISEP. Percentage of Various Energy Power Generation in 2018. 2019. (In Japanese). Available online: https://www.isep.or.jp/ archives/library/11784 (accessed on 8 September 2019).

71. Mudelsee, M. Estimating Pearson's correlation coefficient with bootstrap confidence interval from serially dependent time series. Math. Geol. 2003, 35, 651-665. [CrossRef]

72. Schmid, F.; Schmidt, R. Multivariate extensions of Spearman's rho and related statistics. Stat. Probab. Lett. 2007, 77, 407-416. [CrossRef]

73. Razali, N.M.; Wah, Y.B. Power comparisons of shapiro-wilk, kolmogorov-smirnov, lilliefors and anderson-darling tests. J. Stat. Model. Anal. 2011, 2, 21-33.

74. Pu, S.; Shao, Z.; Fang, M.; Yang, L.; Liu, R.; Bi, J.; Ma, Z. Spatial distribution of the public's risk perception for air pollution: A nationwide study in China. Sci. Total Environ. 2019, 655, 454-462. [CrossRef] [PubMed]

75. Ma, G.; Lin, J.; Li, N.; Zhou, J. Cross-cultural assessment of the effectiveness of eco-feedback in building energy conservation. Energy Build. 2017, 134, 329-338. [CrossRef] 